\title{
Findings in lymph nodes of patients with germ cell tumours after chemotherapy and their relation to prognosis
}

\author{
R J ZUK, B J JENKINS, * J E MARTIN, R T D OLIVER, † S I BAITHUN \\ From the Departments of Morbid Anatomy, ${ }^{*}$ Urology, and †Medical Oncology, The London Hospital, \\ Whitechapel, London
}

SUMMARY One hundred and forty six patients with advanced germ cell testicular tumours (38 seminomas and 108 malignant teratomas) treated by combination chemotherapy were studied over 10 years. Most of the improvement seen was in patients with malignant teratoma undifferentiated. In the most recently treated patients (1984-1987) $75 \%$ of drug resistant cases were malignant teratoma intermediate compared with $26 \%$ in the series treated between 1978-1983. The microscopic features of 52 primary testicular tumours were compared with features seen in excised retroperitoneal lymph nodes after completion of chemotherapy. Primary malignant teratoma intermediate had a higher incidence of viable malignancy in the excised tissue than malignant teratoma undifferentiated. Mature teratoma or fibronecrotic tissue within resected tissue was associated with a good prognosis. If resection was complete patients with drug resistant malignant teratoma intermediate had a more favourable prognosis than drug resistant malignant teratoma undifferentiated.

It is advised that retroperitoneal node dissection should be considered in the management of patients with advanced germ cell testicular tumours, and that as complete a resection as possible be attempted to avoid the danger of missing residual disease.

Since the introduction of cisplatin into combination chemotherapy for the treatment of patients with metastatic germ cell tumours of the testis (GCTT) most centres have reported a $30 \%$ improvement in the overall survivals without major changes in chemotherapy regimens. ${ }^{1-3}$ This improvement has been due to reduction in the incidence of deaths related to treatment as a result of increasing experience using the regimen, particularly dose intensity of treatment, avoiding delay between treatments, and the judicious use of surgical staging after completion of chemotherapy. Furthermore, treating earlier stage cases due to greater confidence in the ability to produce close to $100 \%$ cure of small volume disease, and dispensing with radiotherapy as treatment of choice for stage I and II disease, has also contributed to better survival.

Despite these major advances in patient management, residual retroperitoneal masses may remain. Lymphangiography, intravenous urography, ultrasound, computerised tomography scanning and

Accepted for publication 25 May 1989 tumour marker assays have all been used to stage GCTT and also to characterise these residual masses, but no reliable criteria as yet have been identified to indicate the precise nature of the tissue. The characteristics of the mass can only be accurately determined by thorough histological examination after surgical excision. ${ }^{45}$ Histological examination of the excised mass shows that the mass can include necrotic tissue or viable tumour, or both. ${ }^{56}$

As the cure rate of undifferentiated GCTT has improved, the small subgroup of patients with drug resistant disease whose tumours show somatic differentiation (malignant teratoma intermediate) are now making up a larger proportion of those with a poor prognosis. Prompted by the relative lack of publications which have looked at the prognostic importance of the criteria used by the British Testicular Tumour Panel ${ }^{7}$ in the light of the recent improvements in the results of treatment, this paper reports the results of a univariate analysis to attempt to do this and appraise the value of surgical staging after treatment in these cases. 


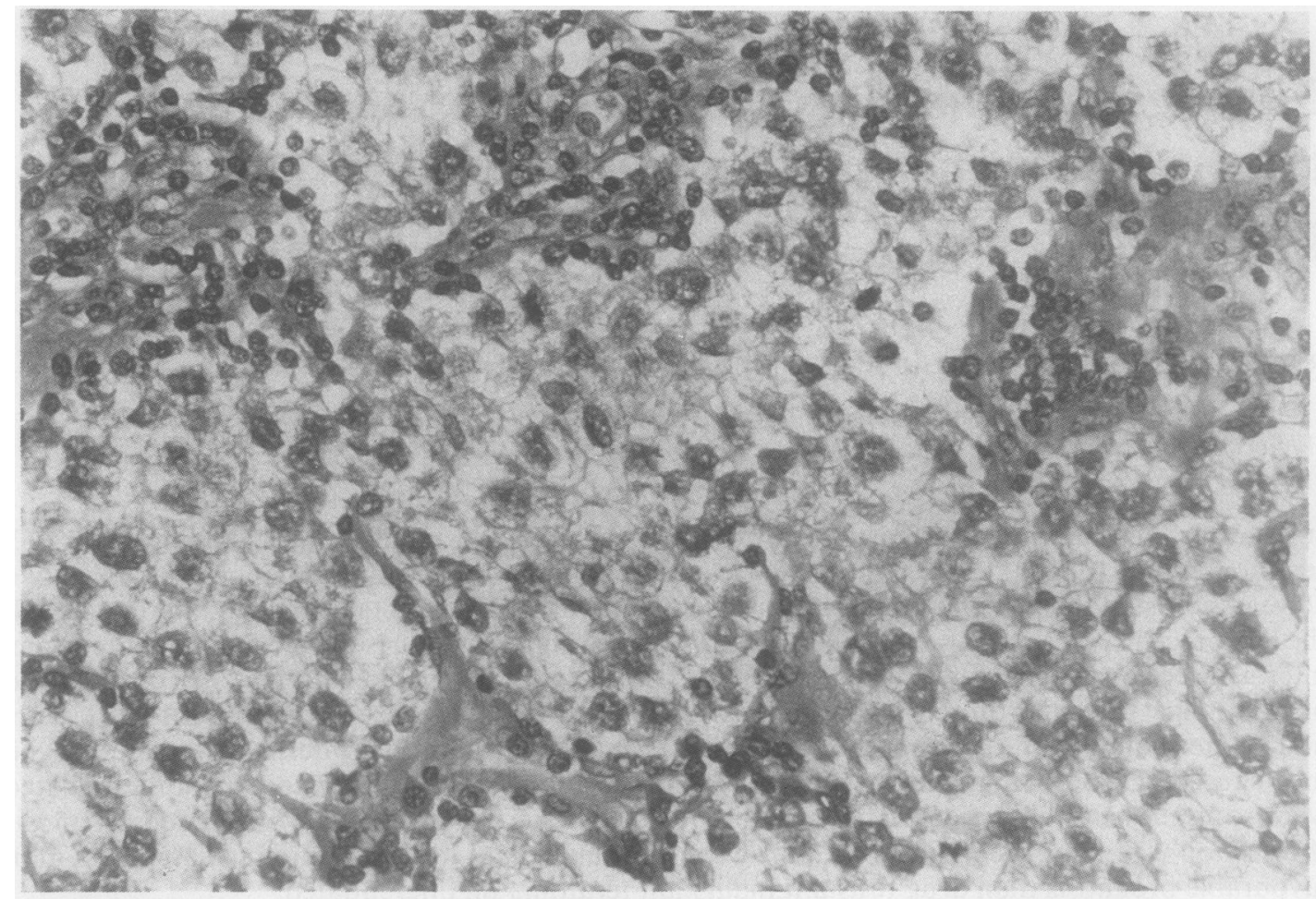

Fig 1 Typical seminoma showing sheets of uniform cells demarcated by fibrous septae containing lymphocytes. (Haematoxylin and eosin.)

\section{Material and methods}

The patients reviewed were all patients with previously untreated metastatic GCTT treated by one of us (RTDO) between 1978 and 1988. Details of treatment regimens have been published elsewhere. ${ }^{23}$ Histological classification was performed according to the British Testicular Tumour Panel (BTTP) ${ }^{7}$ based on the initial review of referral slides or those from the surgical specimens received after treatment. Using these guidelines the histological material was divided into six main groups: (a) seminoma; (b) teratoma differentiated mature; (c) malignant teratoma intermediate; (d) malignant teratoma undifferentiated; (e) malignant teratoma trophoblastic; (f) fibronecrotic tissue/no viable tumour (figs 1,2 , and 3 ). Adult yolksac tumour was present in many of the malignant teratoma intermediate and malignant teratoma undifferentiated tumours, although this did not affect the overall classification. Adult yolk-sac tumour was not recognised by the BTTP when the classification was originally published, but this pattern is now widely accepted by pathologists and clinicians who use the British classification.

\section{Results}

The series consisted of 146 primary testicular tumours; 38 seminomas and 108 malignant teratomas (table 1). The patients with primary testicular seminoma ranged from 32 to 61 years with a mean of 46 years; the patients with malignant teratomas ranged from 17 to 53 years with a mean of 28 years. The three cases in category "others" had inadequate tissue from the needle biopsy specimen for subclassification. The overall disease free survival after chemotherapy for all patients in the series shows values ranging from $87 \%$ for seminoma, $84 \%$ for malignant teratoma undifferentiated, $\mathbf{7 4 \%}$ for malignant teratoma intermediate and the lowest rate of $27 \%$ for malignant teratoma trophoblastic (table 1). The table also shows that most of the improvement since 1978 has been in patients with malignant teratoma undifferentiated and that in the most recently treated patients $75 \%$ of drug resistant cases are malignant teratoma intermediate (six of eight) compared with $26 \%$ (five of 19 ) in the initial series treated between 1978-1983.

Fifty two patients (40 from the initial series and 12 from outside hospitals) underwent retroperitoneal 


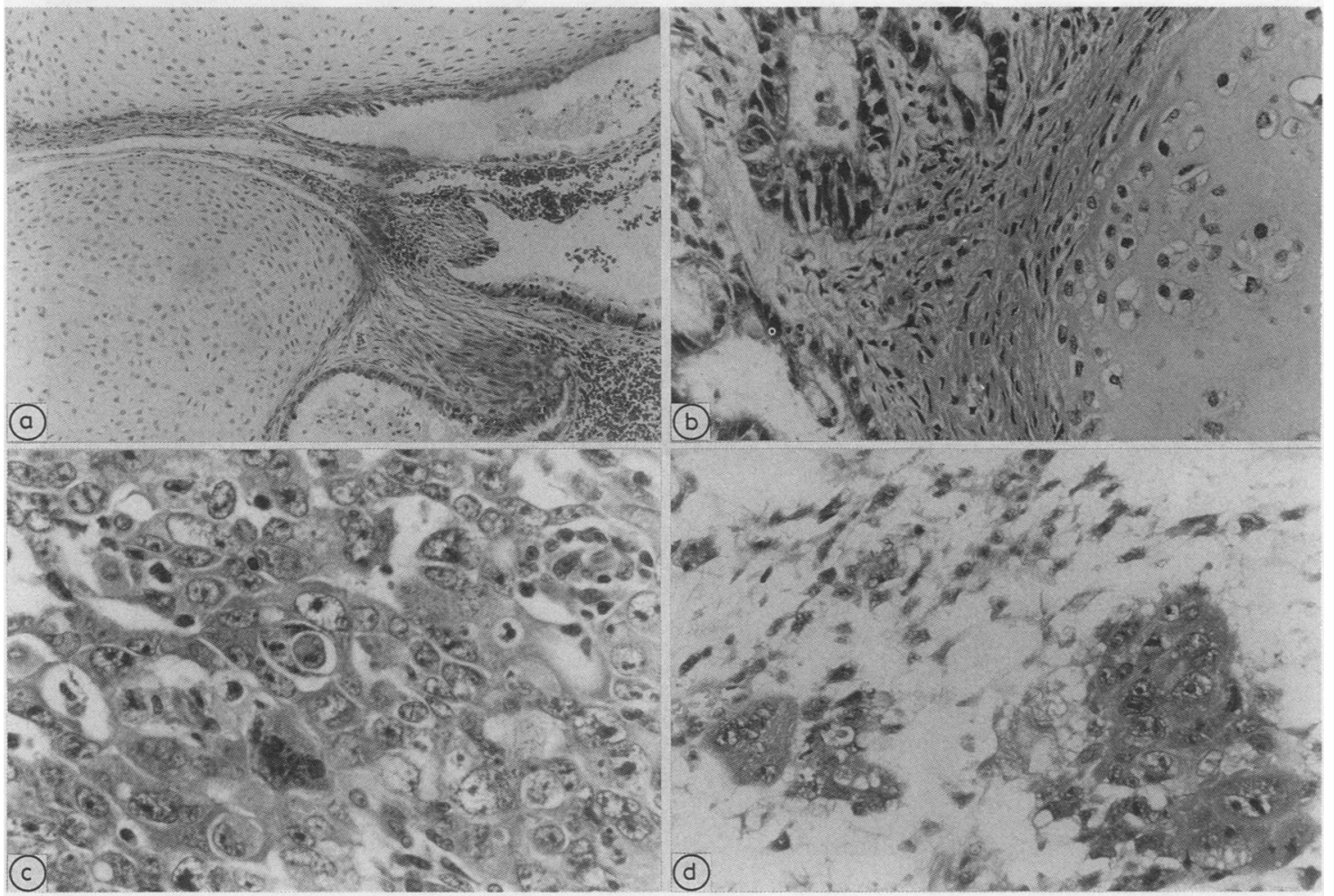

Fig 2 (a) Teratoma differentiated, mature. Islands of cartilage and cystic spaces lined by well developed columnar epithelium. (b) Malignant teratoma, intermediate. Islands of mature cartilage surrounded by undifferentiated carcinoma. (c) Malignant teratoma, undifferentiated. Sheets of anaplastic cancer cells with pronounced cellular and nuclear pleomorphism.

(d) Malignant teratoma, trophoblastic. Groups of large syncytiotrophoblastic and cytotrophoblastic cells. All staining: haematoxylin and eosin.

surgical resection (table 2). Fibronecrotic tissue and residual mature teratoma was found in 16 of $26(62 \%)$, 15 of $16(94 \%)$, and six of seven $(86 \%)$ of primary malignant teratoma intermediate, malignant teratoma undifferentiated, and seminoma, respectively. Malignant teratoma intermediate and malignant teratoma undifferentiated were found in 10 of $26(38 \%)$, one of $16(6 \%)$, and one of seven (14\%) cases of malignant teratoma intermediate, malignant teratoma undifferentiated, and seminomas, respectively. Two cases of malignant teratoma trophoblastic were included in the series with one showing complete necrosis and the other malignant teratoma trophoblastic. One of the patients with mature teratoma in retroperitoneal lymph nodes had areas of squamous carcinoma and rhabdomyosarcoma. This is a rare occurrence which is not recognised by the BTTP but is categorised as mature teratoma with malignant transformation in the

\section{WHO classification. ${ }^{8}$}

The correlation of histological findings after completion of chemotherapy with survival is summarised in table 3 . Eighteen of 20 patients $(90 \%)$ with necrotic tissue, 16 of $18(89 \%)$ with mature teratoma, five of nine $(55 \%)$ with malignant teratoma intermediate, one of three $(33 \%)$ with malignant teratoma undifferentiated and none of two patients with malignant teratoma trophoblastic are alive after surgical resection of retroperitoneal tissues following completion of chemotherapy.

Of the eight patients who had incomplete retroperitoneal resection, six died within two years of surgery (two with malignant teratoma undifferentiated and four with malignant teratoma intermediate disease) and two are still alive (one with residual mature teratoma and one showing fibronecrotic tissue) at the time of writing. 


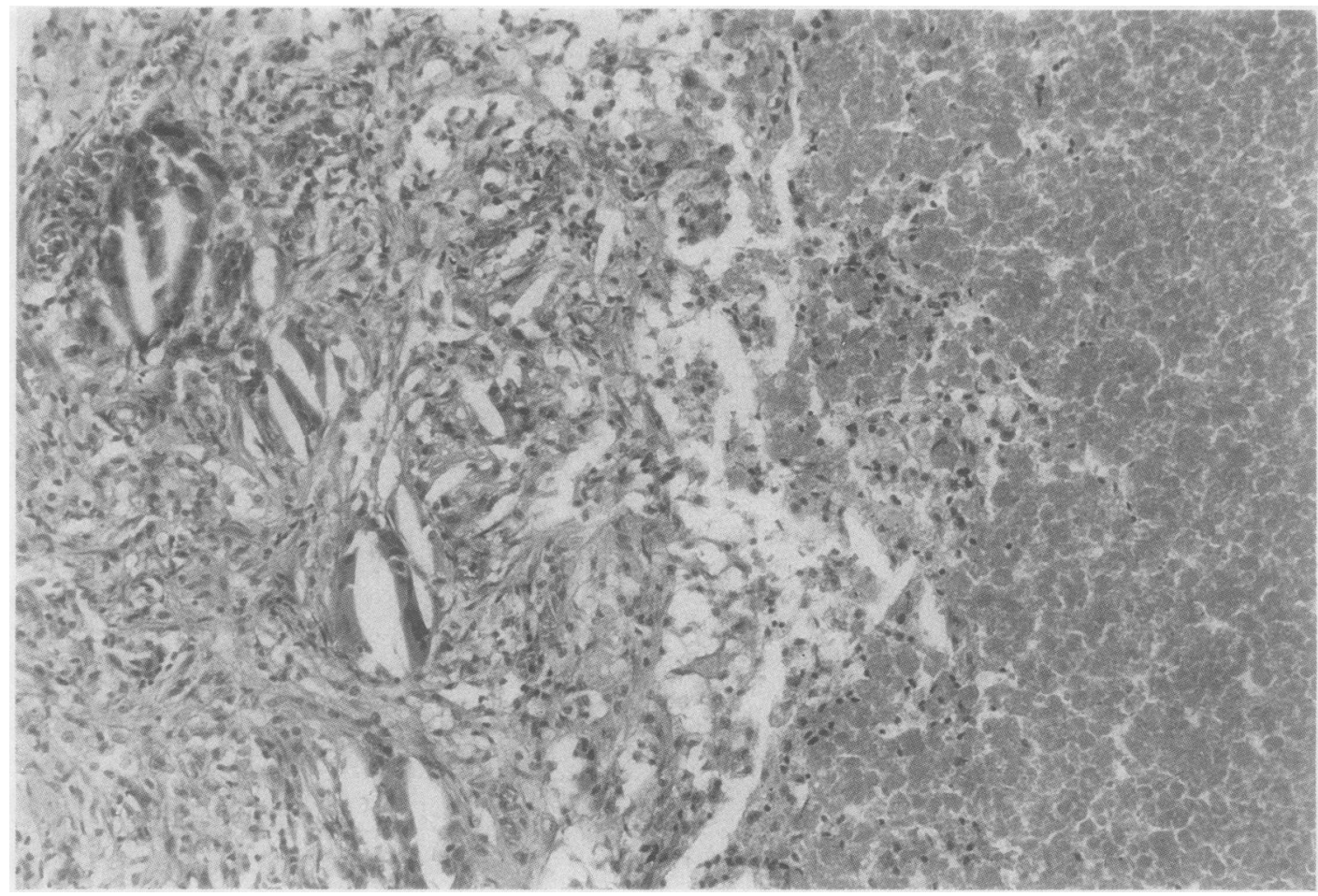

Fig 3 Fibronecrotic tissue. Areas of necrosis on right and granulation tissue containing cholesterol crystal clefts on the left. (Haematoxylin and eosin.)

Table 1 Overall disease free survivals after completion of chemotherapy

\begin{tabular}{lcll}
\hline & & \multicolumn{2}{l}{$\begin{array}{l}\text { Continuous disease free } \\
\text { survival in per cent }\end{array}$} \\
\cline { 2 - 4 } Pathology & Total & $1978-1983$ & $1984-1987$ \\
\hline $\begin{array}{l}\text { Seminoma } \\
\begin{array}{l}\text { Malignant teratoma } \\
\text { undifferentiated }\end{array}\end{array}$ & 38 & 83 & 86 \\
$\begin{array}{l}\text { Malignant teratoma } \\
\text { intermediate }\end{array}$ & 55 & 74 & 100 \\
$\begin{array}{l}\text { Malignant teratoma } \\
\text { trophoblastic }\end{array}$ & 39 & 74 & 80 \\
$\begin{array}{l}\text { Others } \\
\text { Totals }\end{array}$ & 11 & 25 & 33 \\
\hline
\end{tabular}

Table 3 Influence of histology of excised specimens on survival after surgical staging following chemotherapy

\begin{tabular}{|c|c|c|c|}
\hline Histology & $\begin{array}{l}\text { Died of } \\
\text { disease } \\
(\text { No/\% })\end{array}$ & $\begin{array}{l}\text { Died of } \\
\text { intercurrent } \\
\text { illness } \\
(\mathrm{No} / \%)\end{array}$ & $\begin{array}{l}\text { Patients } \\
\text { surviving } \\
(\text { No/\%) }\end{array}$ \\
\hline $\begin{array}{l}\text { Necrotic } \\
\text { Mature }\end{array}$ & $\begin{array}{l}1 / 20(5) \\
1 / 18(6)\end{array}$ & $\begin{array}{l}1 / 20(5) \\
1 / 18(6)\end{array}$ & $\begin{array}{l}18 / 20(90) \\
16 / 18(89)\end{array}$ \\
\hline $\begin{array}{l}\text { Malignant teratoma } \\
\text { intermediate } \\
\text { Malignant teratoma }\end{array}$ & $4 / 9(45)$ & $0 / 9$ & $5 / 9(55)$ \\
\hline $\begin{array}{l}\text { undifferentiated } \\
\text { Malignant teratoma }\end{array}$ & $2 / 3(67)$ & $0 / 3$ & $1 / 3(33)$ \\
\hline trophoblastic & $2 / 2(100)$ & $0 / 2$ & $0 / 2$ \\
\hline
\end{tabular}

Table 2 Correlation of histological findings in germ cell tumours before and after chemotherapy

\begin{tabular}{|c|c|c|c|c|c|c|}
\hline \multicolumn{3}{|l|}{ Before } & \multicolumn{4}{|l|}{ After } \\
\hline & Total & Necrotic & Mature & $\begin{array}{l}\text { Malignant } \\
\text { teratoma } \\
\text { intermediate }\end{array}$ & $\begin{array}{l}\text { Malignant } \\
\text { teratoma } \\
\text { undifferentiated }\end{array}$ & $\begin{array}{l}\text { Malignant } \\
\text { teratoma } \\
\text { trophoblastic }\end{array}$ \\
\hline $\begin{array}{l}\text { Malignant teratoma } \\
\text { intermediate } \\
\text { Malignant teratoma }\end{array}$ & 26 & $2(8 \%)$ & $14(54 \%)$ & $8(31 \%)$ & $2(8 \%)$ & 0 \\
\hline $\begin{array}{l}\text { undifferentiated } \\
\text { Malignant teratoma }\end{array}$ & 16 & $11(69 \%)$ & $4(25 \%)$ & 0 & $1(6 \%)$ & 0 \\
\hline $\begin{array}{l}\text { trophoblastic } \\
\text { Seminoma } \\
\text { No histology }\end{array}$ & $\begin{array}{l}2 \\
7 \\
1\end{array}$ & $\begin{array}{l}1(50 \%) \\
5(71 \%) \\
1\end{array}$ & $\begin{array}{l}0 \\
1(14 \%) \\
0\end{array}$ & $\begin{array}{l}0 \\
1(14 \%) \\
0\end{array}$ & $\begin{array}{l}0 \\
0 \\
0\end{array}$ & $\begin{array}{l}1(50 \%) \\
0 \\
0\end{array}$ \\
\hline
\end{tabular}




\section{Discussion}

Although there have been few substantial reports correlating response to combination chemotherapy with the results of single agent chemotherapy, those that have been done suggest that malignant teratoma undifferentiated was more chemosensitive than malignant teratoma intermediate, ${ }^{9}$ though little interest has been aroused by this observation. When the results of platinum based combination chemotherapy were first reported, there was little prognostic importance attached to histological subtype and interest in morphological staging has declined in recent years.

The results of this analysis suggest that most of the improvement in survival during the past decade since the introduction of cisplatin combination chemotherapy has been in patients with malignant teratoma undifferentiated, while those tumours showing either somatic or trophoblastic differentiation have shown little improvement. Clearly, it will require a larger series to confirm if this is of real importance in a multivariate analysis, and hopefully this will emerge from the multicentre prognostic factor analysis currently in progress under the auspices of the Medical Research Council.

Recent debate has suggested that GCTT may evolve via an in situ stage through seminoma to malignant teratoma undifferentiated. Malignant teratoma undifferentiated, the most undifferentiated state, is then thought to differentiate terminally into specific embryonic and extra-embryonic tissue elements represented by mature teratoma, malignant teratoma intermediate, malignant teratoma trophoblastic and yolk-sac tumour. ${ }^{10}$ These views, however, are still speculative but are supported by recent observations on DNA ploidy values, twin and HLA studies, and electron microscopy analysis on human tumours, ${ }^{1011}$ and from experimental studies on mice. ${ }^{12}$ The main hypothesis on which the British system of classification was originally based proposes that only seminoma arises from germ cells whereas teratomas are derived from blastomeres misplaced early in embryonic development. ${ }^{13}$ In our series two cases of primary testicular seminoma showed mature teratoma and malignant teratoma intermediate in retroperitoneal lymph nodes after chemotherapy. Tissue samples on both cases had been thoroughly sampled and thoroughly examined histologically. Although only two cases are included, this may lend support to the first theory of histogenesis that GCTT pass through seminomatous and malignant teratoma undifferentiated stages which then differentiate into the other elements described above.

Until recently, patients with metastatic GCTT were treated by orchidectomy and either radical lymph node dissection (para-aortic or mediastinal or both) or radiotherapy. As modern chemotherapy for metastatic disease is extremely effective, clinicians have questioned the need for routine retroperitoneal node dissection with its associated risks to the patient of damage to the great vessels ${ }^{14}$ and loss of ejaculation. ${ }^{15}$ Even after radiotherapy there is a risk of death due to marrow toxicity induced by chemotherapy. Various techniques have been used to establish if metastatic testicular carcinoma remains within the retroperitoneal lymph nodes after chemotherapy. Most promise has been shown by measuring serum concentrations of the tumour markers $\beta$-chorionic gonadotrophin and $\alpha$-fetoprotein. When positive, they have a good correlation with histopathological type but there isn't a $100 \%$ correlation between detection in serum and detection in tissue. ${ }^{16}{ }^{17}$ Therefore, the characteristics of retroperitoneal tissues can only be accurately determined by thorough histological examination after surgical excision.

In our study the histological analysis of retroperitoneal tissues shows that malignant teratoma undifferentiated, malignant teratoma intermediate, and malignant teratoma trophoblastic was present in 13 of $52(25 \%)$ patients who had surgical excision. This finding emphasises the fact that once the course of chemotherapy has been completed retroperitoneal nodes may still contain residual disease which provides foci for disease relapse.

In patients showing mature teratoma in retroperitoneal nodes the prognosis was good. Only one died of his disease and the other of intercurrent illness. In the first patient the mass was incompletely excised. Several cases have been reported of the late relapse of mature teratoma both as a GCTT and as sarcomatous or carcinomatous transformation within a mature teratoma. ${ }^{18-20}$ This is emphasised by the finding that one of our cases with mature teratoma in retroperitoneal tissues developed areas of squamous carcinoma and rhabdomyosarcoma. Loehrer et al also reported that in patients in whom it was not possible to remove all mature teratoma, one third were found to have relapsed within five years. ${ }^{18}$

The prognosis was also good for patients in our series with fibronecrotic tissue in retroperitoneal nodes. Only two patients died, one due to intercurrent illness and the other with metastatic disease; in the latter case the fibronecrotic tissue was incompletely excised. Therefore, there remains the possibility that although resected tissue appears totally necrotic histologically, micrometastases of viable tumour may remain undetected leading to disease relapse.

We would therefore advise that retroperitoneal node dissection be considered in the management of patients with advanced GCTT after completion of chemotherapy, and that if it is to be perfomed it must be emphasised that as complete a resection as possible 
should be attempted. Retroperitoneal dissection with resection is a dangerous surgical procedure but the overall morbidity and mortality are low. ${ }^{4}$

In conclusion, we have shown that with increasing experience in the use of combination chemotherapy, patients with metastatic undifferentiated testicular cancer seem to have better disease free survivals than those with intermediate differentiated tumours, and close to that of metastatic seminoma. Retroperitoneal masses remaining after completion of chemotherapy can only be determined accurately by thorough histological examination. Patients with well differentiated testicular tumours on presentation have a high chance of harbouring residual active disease within retroperitoneal tissues after chemotherapy. If mature teratoma or fibronecrotic tissue is present then these patients do have a good prognosis, but the evidence available suggests that if either of these elements remain there is a slight chance of disease relapse, particularly if excision is incomplete. We advise that thorough resection of retroperitoneal nodes be considered in the management of all patients with advanced GCTT following completion of chemotherapy.

We are grateful to our collegues Professor J P Blandy and Messrs W F Hendry, H N Whitfield, P R Riddle, A M I Paris, R C Tiptaft, J P Williams, C R J Woodhouse, M Singh, E P N O'Donoghue, J Wickham and $M$ treatment, and R C B Pugh, K M Cameron, M C Parkinson, D Levinson and R A Risdon who reviewed referral slides and provided classification according to the British Testicular Tumour Panel on some of their patients.

\section{References}

1 Medical Research Council Working Party on Testicular Tumours. Prognostic factors in advanced non-seminomatous germ cell testicular tumours: results of a multicentre study. Lancet 1984; i:8-11.

2 Oliver RTD. Testicular germ cell tumours-a model for a new approach to treatment of adult solid tumours. Postgrad Med J 1985;61:123-31.

3 Oliver RTD, Dhaliwal HS, Hope-Stone HF, Blandy JP. Shortcourse etoposide, bleomycin and cisplatin in the treatment of metastatic germ cell tumours. Appraisal of its potential as adjuvant chemotherapy for stage I testis tumours. $\mathrm{Br} J$ Urol 1988;61:53-8.
4 Williams SN, Jenkins BJ, Baithun SI, Oliver RTD, Blandy JP. Radical retroperitoneal node dissection after chemotherapy for testicular tumours. Br J Urol 1989;63:641-8.

5 Donohue JP, Roth LM, Zachary JM, Rowland RG, Einhorn LH, Williams SG. Cytoreductive surgery for metastatic testis cancer: tissue analysis of retroperitoneal masses after chemotherapy. $J$ Urol 1982;127:1111-14.

6 Tait D, Peckham MJ, Hendry WF, Goldstraw P. Post-chemotherapy surgery in advanced non-seminomatous germ-cell testicular tumours: the significance of histology with particular reference to differentiated (mature) teratoma. $\mathrm{Br} J$ Cancer 1984;50:601-9.

7 Pugh RCB. Testicular tumours. In: Pugh RCB, ed. Pathology of the testis. Oxford: Blackwell Scientific Publications, 1976: 139-59.

8 Bar W, Hedinger CE. Comparison of histologic types of primary testicular germ cell tumours with their metastases: consequences for the WHO and the British nomenclatures? Virchows Arch [Pathol Anat] 1976;370:41-54.

9 Williams C. Current dilemmas in the management of non-seminomatous germ cell tumours of the testis. Cancer Treat Rev 1977;4:275-97.

10 Oliver RTD. HLA phenotype and clinicopathological behaviou of germ cell tumours-possible evidence for clonal evolution from seminomas to non-seminomas. Int J Androl 1987;10: 85-93.

11 Oliver RTD, Blandy JP, Hope-Stone HF. Modern management of germ cell tumours. In: Oliver RTD, Blandy JP, Hope-Stone HF eds. Urological and genital cancer. Oxford: Blackwell Scientific Publications, 1988:359-81.

12 Fox H. Biology of teratomas. In: Anthony PP, MacSween RNM eds. Recent advances in histopathology. Vol 13. London: Churchill Livingstone, 1987:33-43.

13 Pugh RCB, Cameron KM. Teratoma. In: Pugh RCB, ed. Path ology of the testis. Oxford: Blackwell Scientific Publicationsg 1976:199-244.

14 Einhorn LH, Williams SD, Mandelbaum I, Donohue JP. Surgica resection in disseminated testicular cancer following chemo? therapeutic cytoreduction. Cancer 1981;48:904-8.

15 Leiter E, Brendler H. Loss of ejaculation following bilateral retroperitoneal lymphadenectomy. J Urol 1967;98:375-8.

16 Mostofi FK. Tumour markers and pathology of testicular tumours. In: Kurth KM, ed. Progress and controversies in oncological urology. New York: Alan R Liss, 1984:69-87.

17 Butcher DN, Gregory WM, Gunter PA, Masters JRW, Parkinson MC. The biological and clinical significance of HCG-containing cells in seminoma. Br J Cancer 1985;51:473-8.

18 Loehrer PJ, Hui S, Clark S, et al. Teratoma following cisplatinbased combination chemotherapy for nonseminomatous germ cell tumours: a clinicopathological correlation. J Urol 1986;135:1183-9.

19 Logothetis CJ, Samuels ML, Tindale A, Johnson DE. The growing teratoma syndrome. Cancer 1982;50:1629-35.

20 Ahlgren AD, Simrel CR, Tricke TJ, Ozols R, Barsky SH. Sarcoma arising in a residual testicular teratoma after cytoreductive chemotherapy. Cancer 1984;54:2015-18.

Requests for reprints to: Dr S I Baithun, Department of Morbid Anatomy, The London Hospital, Whitechapel, London E1, England. 